\title{
A Study on the Current Situation of Innovation and Entrepreneurship of Chinese College Students
}

\author{
Aijing Liü, a \\ ${ }^{1}$ North China Electric Power University(Baoding), Hebei 071000, China \\ a1228262272@qq.com
}

\begin{abstract}
College students are already the main body of modern innovation and entrepreneurship. Cultivating college students' entrepreneurial ability can not only improve the comprehensive quality of college students and reduce the employment pressure, but also play a vital role in promoting new social development. Based on the current situation of college students 'innovation and entre -preneurship and the present situation of innovation and entrepreneurship education system in colleges and universities, this paper analyzes the practical problems of college students' innovation and entrepreneurship education. Then, we explore innovative and entrepreneurial education practical feasible countermeasures through in-depth analysis of the reasons. Based on the analysis of the status quo of college students' innovation and entrepreneurship education, we find that there are still some problems with the existing innovation and entrepreneurship education system: most students lack a clear understanding of innovation and entrepreneurial spirit and lack entrepreneurial enthusiasm. Due to the marginalization of innovative entrepreneurship education, the imperfect curriculum system, the lack of educational resources and the constraints of traditional educational philosophy, the effect of innovative entrepreneurial courses is very limited. In terms of policy, the propaganda and innovation of college students 'innovation and entrepreneurship policy is not enough, which makes the social and cultural atmosphere of college students' innovation and entrepreneurship is not good enough, and it is difficult to implement it after the policy is formulated.
\end{abstract}

Keywords: Innovation and Entrepreneurship of College Students, Questionnaire.

\section{Introduction}

According to statistics, the proportion of self-employed college students is very low, less than $1 \%$ of the total number of graduates, while the developed countries accounted for $20 \%-30 \%$. Moreover, the data show that the probability of success of Chinese undergraduate graduates is less than $1 \%$, the success rate of master's degree is only 5\%. Tsinghua University Venture Center provides a survey report shows that: for the current status of innovation and entrepreneurship of the current situation, the overall quality of China's innovative entrepreneurial team and the current needs of social development there is still a big gap between. In addition, the average level of entrepreneurship education in China is lower than that of the whole world, and the awareness of Chinese college students is relatively low. And most of the students in China is to survive for the survival of the survival of entrepreneurship, which is relatively low level of entrepreneurship. In addition, the success rate of Chinese college students is far lower than the developed countries.

In view of the importance of studying the innovation and entrepreneurship of Chinese college students, this study has carried on the research to the teachers and students of colleges and universities in Beijing, Hebei and other places in China, so as to understand the current situation of Chinese college students' innovation and entrepreneurship education and improve the innovation and entrepreneurship education system explore.

\section{Significance}

- Follow the trend of the development of the times, while responding to the call of the state, and promote social and economic development . 
- Reveal the problems of Chinese college students in innovation and entrepreneurship, and explore effective solutions.

- Promote the innovation of innovative entrepreneurship education and try to construct a new model of cultivating innovative entrepreneurship talents.

- To start employment with entrepreneurship, and to achieve the overall development of college students.

\section{Survey design}

In order to accurately and comprehensively understand the status quo of innovation and entrepreneur -ship of college students and to find out the main problems in the innovation and entrepreneurship education in colleges and universities, according to the actual needs, we can start from the innovation and entrepreneurial activities of several college students and the situation of innovation and entrepreneurship education Conducted a questionnaire survey and material collection, and the use of software, such as questionnaire, Epidata and SPSS software to integrate the data, made the following statistics and analysis:

Table 1 Summary of survey numbers

\begin{tabular}{|c|c|c|c|c|c|c|c|c|}
\hline & total & teachers & students & boys & girls & Freshman & Sophomore & Postgraduate \\
\hline $\begin{array}{c}\mathrm{H} \\
\text { University }\end{array}$ & 1184 & 136 & 1048 & 574 & 474 & 624 & 417 & 5 \\
\hline $\begin{array}{c}\mathrm{X} \\
\text { University }\end{array}$ & 1079 & 56 & 1023 & 637 & 386 & 579 & 439 & 6 \\
\hline $\begin{array}{c}\mathrm{C} \\
\text { University }\end{array}$ & 882 & 32 & 850 & 401 & 449 & 463 & 382 & 5 \\
\hline $\begin{array}{c}\mathrm{B} \\
\text { University }\end{array}$ & 642 & 12 & 630 & 361 & 269 & 363 & 263 & 4 \\
\hline
\end{tabular}

\section{The Status Quo of Modern College Students' Innovation}

College students as a new force in society, has gradually become the backbone of China's innovation and entrepreneurship. However, in the process of innovation and entrepreneurship of college students, they will inevitably have some understanding of innovation and entrepreneurship or misunderstanding. These lack and misunderstanding of the students themselves limit their innovation and entrepreneurial spirit, resulting in a certain negative impact.

\subsection{College students lack a sense of innovation and entrepreneurship, and their understanding of it is very one-sided}

Although in recent years, the Chinese government has continuously increased the innovation and entrepreneurial support and publicity of college students, but nearly half of the students do not have a clear understanding of these issues on what is innovation and entrepreneurship and how to innovate and start.

We analyze the results of questions 21 and 30 of the student questionnaire and conduct a linear regression analysis of the results of these questions:

Table 2 (Student Questionnaire) Model Analysis Table

\begin{tabular}{|c|c|c|c|c|c|}
\hline \multicolumn{7}{|c|}{ Anova $^{\text {b }}$} \\
\hline Model & Sum of squares & df & Mean Square & F & Sig. \\
\hline Regression & 104.721 & 1 & 104.721 & 95.497 & .000a \\
\hline Residual & 3651.026 & 3550 & 1.097 & & \\
\hline Total & 3755.747 & 3551 & & & \\
\hline $\begin{array}{l}\text { A. predictor variables: 21, Do you know the policy of entrepreneurship } \\
\text { B. dependent variable: 30, (Dan Xuan) have you ever participated in the } \\
\text { competition or activity of innovation or entrepreneurship? }\end{array}$ \\
\hline
\end{tabular}


Table 2 is an Anova model analysis table. The Sig value in the table is zero, and the significant feature is also 0 , which reflects that the hypothesis that college students' participation in innovative entrepreneurial competition or activity is not established due to the understanding of entrepreneurial policy. The probability of small probability event is 0 , less than 0.05 , which shows that college students 'understanding of entrepreneurial policy will have a linear effect on the students' participation in innovation and competition.

Table 3 (student questionnaire) Model Analysis Table

\begin{tabular}{|c|c|c|c|c|c|c|c|}
\hline \multicolumn{8}{|c|}{ Coefficient $^{a}$} \\
\hline \multirow{2}{*}{ Mode1 } & \multicolumn{2}{|c|}{$\begin{array}{c}\text { Unstandardized } \\
\text { Coefficients }\end{array}$} & \multirow{2}{*}{$\begin{array}{c}\text { Standardized } \\
\text { Coefficient } \\
\text { C }\end{array}$} & \multirow{2}{*}{$\mathrm{t}$} & \multirow{2}{*}{ Sig. } & \multicolumn{2}{|c|}{ Linear statistic } \\
\hline & B & $\begin{array}{l}\text { standar } \\
\text { d error }\end{array}$ & & & & Allowance & VIF \\
\hline (Constant) & 3.184 & 0.130 & & 24.555 & 0.000 & & \\
\hline $\begin{array}{c}\text { Do you } \\
\text { understand your } \\
\text { entrepreneurial } \\
\text { policy? }\end{array}$ & 0.437 & 0.045 & 0.29 & 9.772 & 0.000 & 1. 000 & 1. 000 \\
\hline
\end{tabular}

A. Dependent variable: 30 , you are involved in the innovation and entrepreneurship game? How is the result of the match?

Table 3 is the coefficient table. The table shows the 21st question "Do you know about the policy of entrepreneurship?" in the student questionnaire passed the Sig $0 \mathrm{t}$ test, where B was 0.437 and the constant was 3.184. From this we can objectively conclude that the linear equation between question 21 and question 30 in the student questionnaire can be expressed as:

The value of $\mathrm{Q} 30=3.184+0.437 *$ The degree of understanding.

From this formula we can see that there is a linear relationship between question 21 and question 30 in the student questionnaire. As the degree of understanding increases, the degree of good results is linearly increased. This proves that there is a positive impact between them.

\section{2 innovation and entrepreneurial passion, lack of ability}

The rapid development of modern China's economy, especially the implementation of Chinese college students innovation and entrepreneurship training program so that college students innovative ideas and more and more passion. However, the lack of innovative entrepreneurial skills still exist. Many college students, although passionate, but lack the entrepreneurial ability and quality. So they can not achieve their own business.

In today's knowledge economy era, college students need to re-understand the innovation and entrepreneurship. The entrepreneurial education of college students should also guide the entrepreneurship education theory of students' implantation of entrepreneurial genes and service economy transformation and upgrading.

\section{Countermeasures and suggestions}

Today, innovation and entrepreneurship is an important way for college students to grow into talent. In order to meet the needs of social development of talent, and to enable students to better adapt to future employment, colleges and universities should focus on the following aspects to strengthen the innovation of entrepreneurship education:

\subsection{Constructing Innovative Entrepreneurship Interactive Ecosystem}

At present, the innovation and entrepreneurship education of Chinese universities can start from the government level, the university level and the social level. Constructing the Trinity College Students' Innovative Entrepreneurship Education Ecology System of "University, Government and Society". In order to give full play to the government, universities and society in all the resources and 
strength to achieve the interaction between the elements of the organization, mutual promotion. So that students can create a broad platform for innovation and entrepreneurship.

\subsection{Paying Attention to Cultivating Students' Innovative and Entrepreneurial Consciousness}

Students' personal qualities are one of the criteria to measure their abilities. Universities should encourage students to focus on improving their personal qualities, including strong sense of social responsibility, challenging spirit, diligence, firm will and resilience.

\subsection{Improve the curriculum system of innovation and entrepreneurship education}

Based on the successful experience and full investigation of innovative entrepreneurship education at home and abroad, colleges and universities can organize high-level innovative entrepreneurship education experts and some successful entrepreneurs to write suitable high-quality teaching materials and strengthen the top design education of innovation and entrepreneurship. In addition, innovation and entrepreneurship education can be effectively integrated into the cultural quality education and teaching plan and credit system, the establishment of multi-level, three-dimensional innovation of the entrepreneurial education curriculum system.

\subsection{Improve the quality of teachers of innovation and entrepreneurship}

The innovation and entrepreneurial abilities of college students are usually instructed by teachers, and the quality and results of personnel training are also largely dependent on the guidance of teachers. Schools should develop relevant incentives to encourage teachers to guide students to innovation and entrepreneurship. At the same time, schools should focus on teacher innovation and entrepreneurial ability to improve and update the relevant knowledge. In addition, universities should actively carry out teacher training activities, such as expert lectures, innovative business platform and so on. The schools should also actively study the development experience of colleges and universities at home and abroad.

\section{References}

[1] Xianguo. College students entrepreneurship education course [M]. Liaoning: Liaoning Normal University Press, 2006.

[2] Chen Yujuan. College students innovation and entrepreneurship education research - Hebei Province as an example [D]. Hebei Normal University, 2011,6.

[3] Wang Yan. Entrepreneurial university: the research of American research university model change [D]. Hangzhou: Zhejiang University, 2005,67.

[4] Rebecca S, Luo Wen. Ye Fu Gui, Luo Yan translation. Creation of the Cold War University Stanford University transition [M]. Beijing: Tsinghua University, 2007,185,213.

[5] Henry Ezkowitz. Wang Sunyu, Yuan Bentao and other translations. Massachusetts Institute of Technology and the rise of entrepreneurial science [M]. Beijing: Tsinghua University Press, 2007,65-69.

[6] Wang Hailong. Research on Entrepreneurship Education in Chinese Universities [D]. Tianjin: Tianjin University, 2004.6

[7] Li Jieyao. On the Path of Innovation and Entrepreneurship Education in Colleges and Universities [D]. Changchun: Changchun University of Technology, 2011.5.

[8] Ma Yonghong, Wan Yu, Li Hanbang. Innovative Education in American Universities from Two Entrepreneurship Programs [J]. China Higher Education, 2010 (11).

[9] Guan Xiaohui and so on. Research and Practice of Innovative Entrepreneurship Education for College Students [J]. China Electric Power Education, 2010 (4) 